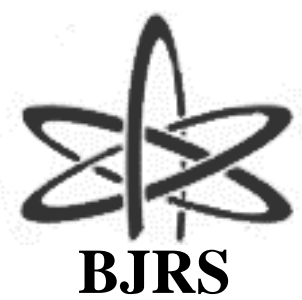

\author{
BRAZILIAN JOURNAL \\ $\mathrm{OF}$ \\ RADIATION SCIENCES \\ 07-02A (2019) 01-14
}

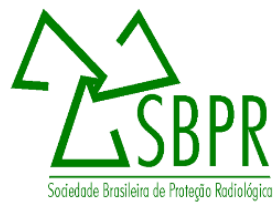

\title{
Chemical characterization of ancient pottery from the south-west Amazonia using Instrumental Neutron Activation Analysis
}

\author{
P. R. Carvalho ${ }^{\text {a }}$ C. S. Munita ${ }^{\text {a }}$ E. G. Neves ; C. A. Zimpel ${ }^{\mathrm{b}}$ \\ ${ }^{a}$ Instituto de Pesquisas Energéticas e Nucleares, Av. Professor Lineu Prestes 2242, 05508-000, São Paulo, SP, Brazil \\ ${ }^{b}$ Museu de Arqueologia e Etnologia, Av. Professor Almeida Prado 146, 05508-070, São Paulo, SP, Brazil \\ patricia.ramos.carvalho@usp.br
}

\begin{abstract}
The analyzes carried out in this work aims to contribute to the discussion about the ceramic objects founded in Monte Castelo's sambaqui located at south-west Amazonia. The first study accomplished by Miller in 1980 suggests that this archaeological site is inserted in the oldest contexts of production of ceramics in the Amazon. Until today, there aren't any physical and chemical analysis performed in this ceramics and this kind of studies may help archaeological researches at the sambaqui. This work presents a preliminary study of chemical characterization of eighty-four ceramic samples using instrumental neutron activation analysis (INAA) by means of the determination of $\mathrm{Na}, \mathrm{K}, \mathrm{La}, \mathrm{Sm}, \mathrm{Yb}$, $\mathrm{Lu}, \mathrm{U}, \mathrm{Sc}, \mathrm{Cr}, \mathrm{Fe}, \mathrm{Co}, \mathrm{Zn}, \mathrm{Rb}, \mathrm{Cs}, \mathrm{Ce}, \mathrm{Eu}, \mathrm{Hf}$ and Th. With the purpose to study the similarity/dissimilarity between the samples, cluster and discriminant analysis were used. The results showed the existence of three different chemical groups whose dating ranging 3000 b.P. to 1500 b.P. that are in agreement with the archaeological studies made by Miller and suggest Bacabal's phase as the oldest ceramist culture in the Southwest of the Amazon.
\end{abstract}

Keywords: instrumental neutron activation analysis, Monte Castelo archaeological site, Thermoluminescence dating.

ISSN: 2319-0612

Accept Submission: 2018-10-30 


\section{INTRODUCTION}

One of the main objectives in Archaeology is the study of objects or vestiges from a remote society with the aim of understanding its history, establishing cultural identities or reconstructing economic and political aspects [1].

In many parts of the world pottery fragments are the most common type of artifact due to their high resistance to most physical-chemical soil conditions. Their macroscopic characteristics make them useful cultural and chronological indicators in Archaeology [2].

Although the study of ceramics in terms of macroscopic characteristics was central to the archaeological interpretation of a site, region or period, ceramics can be examined in terms of mineral and chemical composition, variations in production and firing methods, and stratigraphic and regional distribution. These information along with the knowledge used in the practices of village potters, can sometimes be useful in better understanding the social, economic, and political aspects of past cultures.

The use of an adopted method from the natural sciences is currently subsumed under the term Archaeometry, that is an interdisciplinary field of research that covers aspects of analytical chemistry and spectroscopy, electrochemistry, physics, electrochemistry, anthropology, among other fields [3].

In archaeometric studies on possible clay sources the determination of trace elements are important due they are found typically dispersed in nature, and their concentration profiles depends on the igneous rock formation and contribute to differentiate between ceramic materials made of different clays, which are formed by weathering of the original rocks $[4,5]$, as expressed in the provenance postulate [6-8]. Currently, analytical techniques have been applied for the determination of trace elements. Among the techniques the instrumental neutron activation analysis (INAA) associated with high resolution gamma ray spectrometry has been the most used because it has several advantages such as high sensitivity, precision and accuracy, essential characteristics to detect small variations in the concentration of the chemical elements contained in the ceramic fragments, at trace or ultratrace level. In addition, a very small sample mass is used in the analysis, which is extremely convenient in the case of archaeological material [8-15]. 
Additional studies about the age of the archeological objects are important to establishing the chronology of archaeological sites. The techniques of archaeological dating usually employed vary in their scope (minimum and maximum age) and in the nature of the materials to be dated. With regard to ceramic materials, the dating can be performed by means of Thermoluminescence (TL) dating. Dating by TL technique is a particular application of dosimetry in which there is a source of constant irradiation (the natural radioactivity from radionuclides in the soil where the ceramics is buried). In the case of ceramics, the ionic crystals are the quartz grains contained in the clay from which the ceramics are made. The zeroing of the archaeological clock is defined by the moment the clay mould is heated to high temperature to produce ceramics [16-18]. The accumulated dose $\left(D_{\mathrm{ac}}\right)$ is determined from the ratio $\mathrm{TL}_{\mathrm{ac}} / \mathrm{TL}_{0}$ where $\mathrm{TL}_{\mathrm{ac}}$ is the $\mathrm{TL}$ value obtained from a given mass of quartz grains and $\mathrm{TL}_{0}$ is the TL emitted by annealed quartz grains of same mass. Finally, annual dose rate $\left(D_{a n}\right)$ is calculated from measurements of the radioactive elements within the material and its surroundings where the pottery was collected and from the radiation dose rate from cosmic rays. The age of the pottery can be calculated by the $\mathrm{D}_{\mathrm{ac}}$ divided by the $\mathrm{D}_{\mathrm{an}}$.

This work is an interdisciplinary study involving the application of two physical analytical techniques to Amazonian archaeological fragments from Monte Castelo. INAA was applied for quantitative determination of trace and some microelements in ceramic material and TL was applied for the age determination of the pottery. The samples analyzed in this work were collected and provided by the Museum of Archeology and Ethnology of the University of São Paulo.

\subsection{Archaeological framework}

The Amazon system is the largest and most complex terrestrial ecosystem. Its area includes nine Latin American countries, due to its large size, this area can be seen as a demographic void [19, 20]. However, archaeological research in the region has shown a very different picture. Archaeological remains founded in different areas indicate an age-old history of human occupation. With this perspective, some archaeological currents concentrate on the search of traces of human occupation to prove that before the arrival of the Europeans to the continent, the Amazon was dense and diversely occupied [21]. 
One of the focuses of these searches has been the study of pottery, which are one of the materials most produced and are especially well suited to derive archaeological information and help understanding the way of life of the populations due to its abundance and variety [22].

In the Amazon, the older contexts of pottery production are always associated with sambaquis. The Monte Castelo's sambaqui is one of the oldest contexts of pottery production in the Amazon and is located in the alluvial plain of the Branco River, about $20 \mathrm{~km}$ from its confluence with the Guapore River [23].

The first intervention in the site was made by Miller in 1980 and indicated large quantities of ceramic fragments, lithic artifacts, plant remains, and abundant wildlife including snail of the genus Pamacea that constitute the matrix of sambaqui.

The dates of Monte Catelo's sambaqui (at total 22 dates of ${ }^{14} \mathrm{C}$ ) allow the reconstruction of a sequence of cultural development, that identifies a long pre-ceramic occupation of 8400 years old called as Cupim's phase, followed by the Sinimbu's phase of 7100 years old, and the sudden appearance of Bacabal's phase of 4000 years old. Miller was unable to continue his work due to a malaria attack and has not returned the excavations. However, his preliminary experience demonstrate a high potential that one of the oldest ceramic technologies on the continent belonging to Bacabal's phase can be deposited in the site.

Currently, the researchers at the Monte Castelo archaeological site were taken up and are coordinated by Prof. Eduardo Góes Neves, from the University of São Paulo. The study of Monte Castelo is interesting to performing detailed stratigraphic analyzes, collection of samples for dates and physicalchemical analysis aiming to obtain information that will help in the search for information of the human occupation of the Guaporé River, within the framework of ongoing research on the production of cultural variability in the Amazonian southwest

\section{MATERIALS AND METHODS}

The approach adopted in this work comprises the sampling of ceramic material from Monte Castelo archaeological site, with unknown origin of raw materials. INAA was carried out for the 
determination of the elemental concentration profiles. Due to the number of variables generated, multivariate pattern recognition were applied for grouping samples with similar elemental composition. In addition, studies about the age of the archeological objects were done in order to verify and confirm the contemporaneity of the site and to compare with reference chronology in the literature.

\subsection{Sample preparation to Instrumental neutron activation analysis (INAA)}

A total of 84 ceramic samples were analyzed. These materials were collected during the reopening of excavations at the Monte Castelo's sambaqui and represent the stratigraphy from the surface down to the levels associated with the more complex contexts (concentrated in 0-80 cm).

The external surface was removed with a fine bristle brush. After this procedure, holes were made on the samples with a tungsten carbide rotary file, attached to a variable speed drill. Around $500 \mathrm{mg}$ of powdered sample was obtained from three to eight holes on the side surface of the ceramic fragment, preventing the drill from crossing over the walls.

This powder is then collected, dried for $24 \mathrm{~h}$ in an oven at $100{ }^{\circ} \mathrm{C}$ and stored in desiccators [5], until it is cold enough for weighing. Around $100 \mathrm{mg}$ of each sample were weighed in polyethylene involucres and sealed with sealing iron. Each involucre was wrapped in aluminum foil. Groups of up to seven ceramic powdered samples and two reference materials, the Standard Reference Material - NIST-SRM 1633b (Constituent Elements in Coal Fly Ash) used as standard for analysis and the reference material IAEA Soil-7 (Trace Elements in Soil) used for the analytical quality control, were irradiated in the swimming pool research reactor IEA-R1 of the Instituto de Pesquisas Energéticas e Nucleares (IPEN-CNEN/SP), at a thermal neutron flux of $1.10^{11} \mathrm{~cm}^{2} \cdot \mathrm{s}^{-1}$ for $8 \mathrm{~h}$. The gamma-ray spectrometry was carried out with a hyperpure germanium detector (model GX 2519 from Canberra), with a resolution of $1.90 \mathrm{keV}$ at the $1332 \mathrm{keV}$ gamma peak of ${ }^{60} \mathrm{Co}$. The spectra were collected by a Canberra S-100 MCA with 8,192 channels. The software Genie-2000 NAA Processing Procedure, developed by Canberra, was used to analyze the gamma-ray spectra. Two measurement series were carried out. The elements $\mathrm{Na}, \mathrm{K}, \mathrm{La}, \mathrm{Sm}, \mathrm{Yb}$, Lu and U were measured after 7 days of decay. The elements $\mathrm{Sc}, \mathrm{Cr}, \mathrm{Fe}, \mathrm{Co}, \mathrm{Zn}, \mathrm{Rb}, \mathrm{Cs}, \mathrm{Ce}, \mathrm{Eu}, \mathrm{Hf}$ and Th were measured after 25-30 days of decay [24]. 


\subsection{Sample preparation to Thermoluminescence (TL) dating}

The entire surfaces of the ceramics were polished and they were gently crushed. After sieving, grains sizes between 0.080 and $0.0180 \mathrm{~mm}$ in diameter were chemically treated to obtain pure quartz grains for TL readings. The powder was then immersed in a $30 \%$ solution of $\mathrm{H}_{2} \mathrm{O}_{2}$ to eliminate the organic materials. Posteriorly, the residue was rinsing in destilled water and then immersed in a $20 \%$ solution of hydrofluoric acid (HF) for $45 \mathrm{~min}$. The expected effect of HF is to corrode a thin layer of the surface of quartz grains in order to both clear the surface and to eliminate the $\alpha$-particle effects. After rinsing in distilled water, the sample was treated with $20 \%$ solution of hydrochloric acid for 3 hours, to eliminate the carbonates and organic materials, to be finally washed again in distilled water.

The protocol MAR (Multiple Aliquot Regeneration) was used to determine the equivalent $\mathrm{D}_{\mathrm{ac}}$ in the samples. The samples were divided into several fractions, with approximately $4 \mathrm{mg}$. One fraction was used to measure natural TL (without irradiation in the laboratory and adequately protected from any exposure to light or heat treatment). The other fractions, used for the regenerative doses, were subjected to a heat treatment, where the samples were heated from room temperature to the final temperature of $500{ }^{\circ} \mathrm{C}$, with a heating rate of $5{ }^{\circ} \mathrm{C} /$ second remaining at $500{ }^{\circ} \mathrm{C}$ per 10 seconds to erase the natural TL signal. After zeroing its natural TL signal, regenerative doses were used to raise the calibration curve. The regenerative dose samples were then warmed from room temperature to the final temperature of $200{ }^{\circ} \mathrm{C}$ with a heating rate of $5{ }^{\circ} \mathrm{C} /$ second remaining at $200{ }^{\circ} \mathrm{C}$ for 10 seconds to erase the TL signal from the peaks of low temperatures that are very unstable, then measurements of TL were made in a Ris $\varnothing$ TL/OSL Luminescence Reader Model TL/OSL DA-20 equipped with a ${ }^{90} \mathrm{Sr} /{ }^{90} \mathrm{Y} \beta$ radioactive source with a dose rate of $0.081 \mathrm{~Gy} / \mathrm{second}$. The annual dose value was estimated from uranium, thorium and potassium concentrations obtained by INAA. 


\section{RESULTS AND DISCUSSION}

One of the basic premises underlying the use of chemistry in ceramic analysis is that clay sources can be differentiated if an adequately precision analytical technique is used. If an element is not measured with good precision it can obscure real differences in concentration and the discriminating effect of other well-measured elements tends to be reduced. These differences can be used to form ceramic compositional groups because vessels manufactured from a given clay source will be more similar to each other than to other type of vessels which were manufactured from a different source [24].

In this work the precision was studied using the reference material IAEA Soil-7. For that, were made 14 independent determinations. The mean, the standard deviation (SD) and the relative standard deviation (RSD) were calculated. Table 1 show the results obtained These results were compared with the certified values.

As can be seen at the Table 1 the relative standard deviation (RSD) of $\mathrm{Na}, \mathrm{K}, \mathrm{La}, \mathrm{Sm}, \mathrm{Sc}, \mathrm{Cr}, \mathrm{Fe}$, $\mathrm{Co}, \mathrm{Cs}, \mathrm{Ce}, \mathrm{Eu}$ and Th was less than $10 \%$ and are similar to those from the Confidence interval. In this study all the elements with precision of less than $10 \%$ were considered for interpretation of the results. This precision is considered appropriate by several authors for the choice of the chemical elements for studies of archeological objects using multivariate statistical methods [25].

Although Co had RSD around 7\%, was not included in the data set because the concentration can be affected by tungsten carbides files [26].

Based on these screening criteria, 11 elements: $\mathrm{Na}, \mathrm{K}, \mathrm{La}, \mathrm{Sm}, \mathrm{Sc}, \mathrm{Cr}, \mathrm{Fe}, \mathrm{Cs}, \mathrm{Ce}, \mathrm{Eu}$ and Th were used in subsequent data analyses. None of these elements considered contained missing values.

Initially at the mass fraction of the ceramic samples was made a transformation to compensate for the difference in magnitude and to homogenize the weights of the variables inmultivariate analysis. In archaeometric studies, the elemental concentrations are frequently logarithmically transformed, based on the assumption that the trace elements have a natural lognormal distribution [27-29]. In the present work, the elemental concentrations were rescaled to base-10 logarithms. 
Table 1: Results for IAEA Soil 7 in $\mu \mathrm{g} / \mathrm{g}$, unless otherwise indicated, $\mathrm{n}=14$.

\begin{tabular}{cccccc}
\hline Element & Radioisotope & $\begin{array}{c}\text { Main energy } \\
\text { used }(\mathbf{k e V})\end{array}$ & Mean \pm SD & RSD $(\%)$ & 95\% Confidence interval \\
\hline $\mathrm{Na}(\mathrm{mg} / \mathrm{g})$ & ${ }^{24} \mathrm{Na}$ & 1368.40 & $2.35 \pm 0.08$ & 3.54 & $(2.30-2.50)$ \\
$\mathrm{K}(\mathrm{mg} / \mathrm{g})$ & ${ }^{42} \mathrm{~K}$ & 1524.60 & $12.39 \pm 0.70$ & 5.62 & $(11.30-12.70)$ \\
$\mathrm{La}$ & ${ }^{140} \mathrm{La}$ & 1596.20 & $30.81 \pm 0.88$ & 2.87 & $27.00-29.00$ \\
$\mathrm{Sm}$ & ${ }^{153} \mathrm{Sm}$ & 103.20 & $5.59 \pm 0.27$ & 4.77 & $4.80-5.50$ \\
$\mathrm{Yb}$ & ${ }^{175} \mathrm{Yb}$ & 396.30 & $2.29 \pm 0.29$ & 12.55 & $1.90-2.60$ \\
$\mathrm{Lu}$ & ${ }^{177 m} \mathrm{Lu}$ & 208.40 & $0.36 \pm 0.04$ & 10.47 & $(0.10-0.40)$ \\
$\mathrm{U}$ & ${ }^{239} \mathrm{~Np}{ }^{1}$ & 228.20 & $2.45 \pm 0.64$ & 26.32 & $2.20-3.30$ \\
$\mathrm{Sc}$ & ${ }^{46} \mathrm{Sc}$ & 889.30 & $8.71 \pm 0.19$ & 2.14 & $6.90-9.00$ \\
$\mathrm{Cr}$ & ${ }^{51} \mathrm{Cr}$ & 320.10 & $68.74 \pm 4.14$ & 6.02 & $49.00-74.00$ \\
$\mathrm{Fe}(\mathrm{mg} / \mathrm{g})$ & ${ }^{59} \mathrm{Fe}$ & 1099.30 & $26.08 \pm 0.72$ & 2.75 & $(25.20-26.30)$ \\
$\mathrm{Co}$ & ${ }^{60} \mathrm{Co}$ & 1332.50 & $9.11 \pm 0.40$ & 4.37 & $8.40-10.10$ \\
$\mathrm{Zn}$ & ${ }^{65} \mathrm{Zn}$ & 511.00 & $93.03 \pm 13.29$ & 14.29 & $101.00-113.00$ \\
$\mathrm{Rb}$ & ${ }^{86} \mathrm{Rb}$ & 1077.00 & $60.50 \pm 13.72$ & 22.69 & $47.00-56.00$ \\
$\mathrm{Cs}$ & ${ }^{134} \mathrm{Cs}$ & 795.80 & $4.97 \pm 0.21$ & 4.19 & $4.90-6.40$ \\
$\mathrm{Ce}$ & ${ }^{141} \mathrm{Ce}$ & 145.40 & $60.19 \pm 0.99$ & 1.64 & $50.00-63.00$ \\
$\mathrm{Eu}$ & ${ }^{152} \mathrm{Eu}$ & 1408.00 & $1.02 \pm 0.10$ & 9.94 & $0.90-1.30$ \\
$\mathrm{Hf}$ & ${ }^{181} \mathrm{Hf}$ & 482.20 & $5.06 \pm 0.60$ & 11.90 & $4.80-5.50$ \\
$\mathrm{Th}$ & ${ }^{233} \mathrm{~Pa}{ }^{2}$ & 312.20 & $8.19 \pm 0.51$ & 6.24 & $6.50-8.70$ \\
\hline
\end{tabular}

${ }^{1} \mathrm{U}$ was determinate by the reaction ${ }^{238} \mathrm{U}(\mathrm{n}, \gamma){ }^{239} \mathrm{U} \stackrel{\beta}{\longrightarrow}{ }^{239} \mathrm{~Np}$.

${ }^{2}$ Th was determinate by the reaction ${ }^{232} \mathrm{Th}(\mathrm{n}, \gamma){ }^{233} \mathrm{Th} \stackrel{\beta}{\longrightarrow}{ }^{233} \mathrm{~Pa}$.

After logarithmic transformation the data set was submitted to outlying tests. Many multivariate methods are sensitive to outliers and it is convenient to identify and remove them before analysis. The quadratic Mahalanobis distance matrix between each sample coordinates vector and the mean vector was calculated by a routine developed in Scilab software. The values were compared with the critical value of Wilks for identification of multivariate outliers [30]. Only two samples were considered an outlier and were removed before analysis.

In order to determine the existence of groups in the data set according to similar or distinct chemical groups two multivariate statistical analysis were used: cluster and discriminant analysis [29].

Cluster analysis is a multivariate statistical technique used to produce behavioral patterns in experimental results through the formation of homogeneous groups of samples [29]. The results of cluster analysis are commonly presented in the form of dendrograms which show the order and 
levels of specimen clustering. In this work, the statistical program $\mathrm{R}$ was used to perform the cluster analysis as a preliminary classification of the results, adopting the squared Euclidean distance and Ward's method as the clustering algorithm, thus generating the dendrogram of the Figure 1.

Figure 1: Dendrogram of the ceramic samples using squared Euclidean distance and Ward's method, $(n=82)$

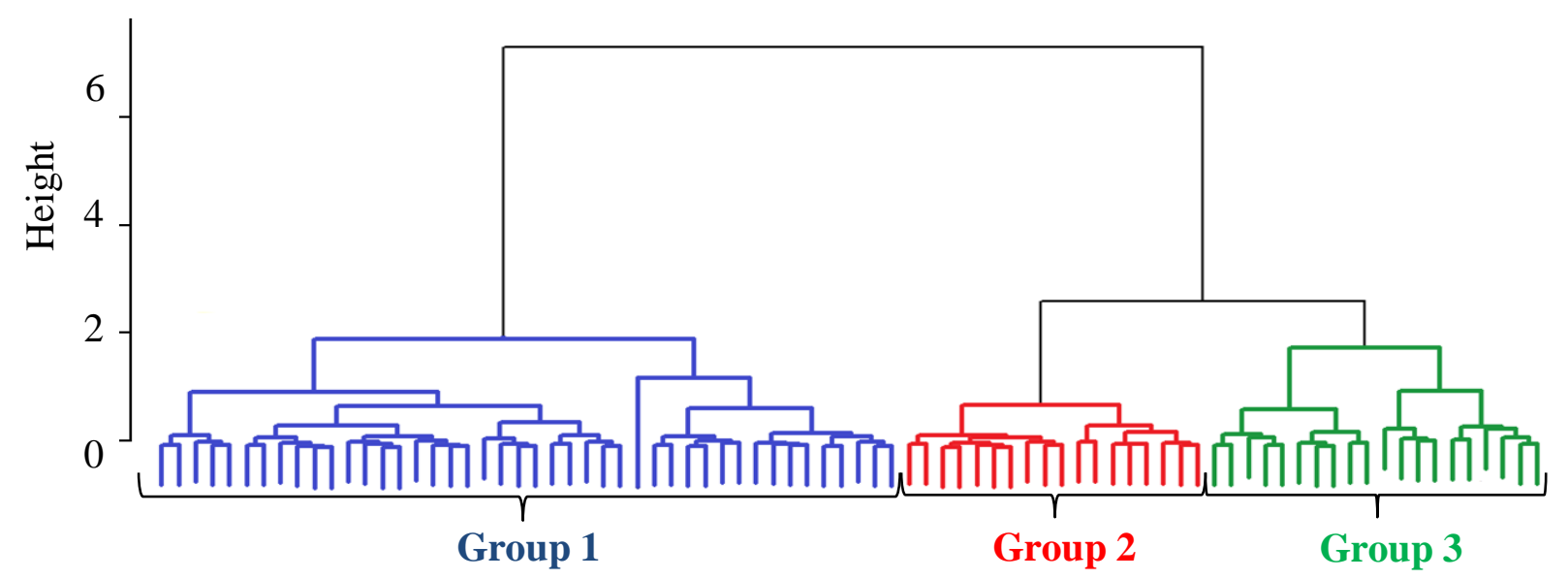

As can be seen in the Figure 1 the preliminary classification showed the existence of three groups very well defined.

After the clustering procedure, a discriminant analysis was carried out in order to verify the data structure. The basis for all multivariate analyses is that all the elements included are independent variables. This is not necessary true, but it can be tested using the pooled within-groups correlation matrix provided by discriminant analysis [29]. After identifying the cluster within samples, discriminant analysis was used to isolate those variables which can most effectively reveal the differences between clusters and establish a discriminant function for this purpose.

The plot obtained by the linear discriminant function 1 versus the linear discriminant function 2 is presented in Figure 2.

As shown in the Figures 1 and 2, the plots reveals three chemical groups, showing that the samples are different in their chemical composition. As can be seen in the figures, three different row material in the ceramics production in the Monte Castelo archaeological site was used. 
Figure 2: Plot of the linear discriminant function 1 vs linear discriminant function 2

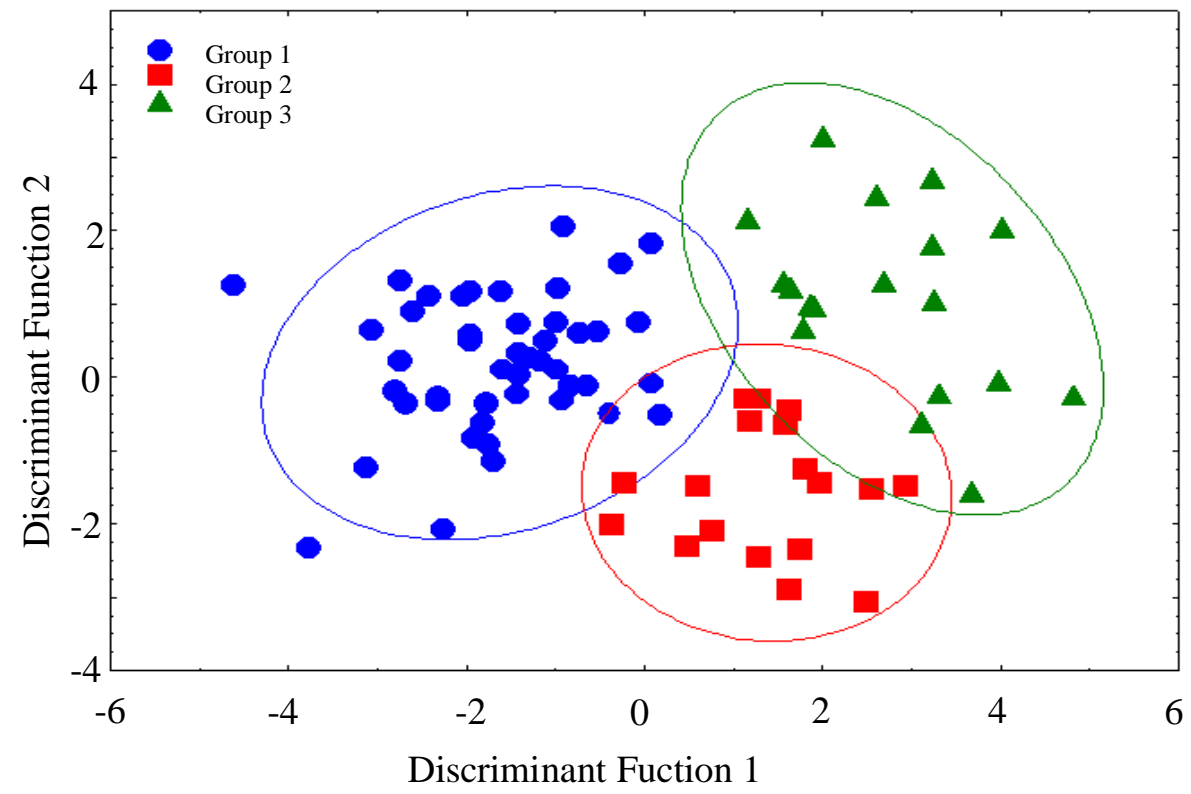

In order to study the temporal space, six pottery fragments from Monte Castelo's sambaqui were dated by means of thermoluminescence (TL). In Table 2, the results of dating 6 pottery fragments are shown.

As can be seen at the Table 2, the ages of the samples vary according to the groups, and Group 1 is the oldest, without taking into account the effect of moisture, which can cause up to $10 \%$ error in the ages making the ceramic fragments supposedly considered younger. Although, the two fragments of Group 1 are in agreement with the range of occupation considered for the sambaqui in the literature [23]. The results indicated that the ceramics associated with the Bacabal's phase have occupied the sambaqui at about 3000 b.P. extending up to 1500 b.P.

Table 2: Accumulated dose $D \mathrm{ac}$ in $\mu \mathrm{Gy}$, annual dose rate $D$ an in $\mu \mathrm{Gy}$ and age obtained.

\begin{tabular}{ccccc}
\hline Group & Sample & $\mathbf{D}_{\text {an }}(\boldsymbol{\mu G y})$ & $\mathbf{D}_{\mathbf{a c}}(\mathbf{G y})$ & Age (years) \\
\hline \multirow{2}{*}{$\mathbf{1}$} & CSQCA 84 & $1767 \pm 122$ & $5,69 \pm 0,15$ & $3220 \pm 238$ \\
\cline { 2 - 5 } & CSQCA 87 & $2197 \pm 168$ & $5,29 \pm 0,06$ & $2408 \pm 186$ \\
\hline \multirow{2}{*}{$\mathbf{2}$} & CSQCA 70 & $2106 \pm 159$ & $4,10 \pm 0,10$ & $1947 \pm 154$ \\
\cline { 2 - 5 } & CSQCA 71 & $2862 \pm 190$ & $5,32 \pm 0,20$ & $1859 \pm 142$ \\
\hline \multirow{2}{*}{$\mathbf{3}$} & CSQCA 31 & $3153 \pm 135$ & $4,56 \pm 0,10$ & $1446 \pm 69$ \\
\cline { 2 - 5 } & CSQCA 40 & $2804 \pm 156$ & $4,27 \pm 0,07$ & $1523 \pm 89$ \\
\hline
\end{tabular}


These dates support the hypothesis that in the Monte Castelo can be deposited one of the oldest ceramist culture in the Southwest of Amazonia. The only South American ceramic complex that is older than Bacabal is the Valdivia phase on the coast of Ecuador, which has more than 50 dating from several sites ranging from 5,600 to 4,300 a.P. [31, 32].

This preliminary experience support the hypothesis that the Bacabal's phase is one of the oldest ceramic technologies of the continent and the Monte Castelo archaeological site has the oldest contexts of production of ceramics in the Southwest Amazon.

\section{CONCLUSION}

The preliminary study made in the Monte Castelo's sambaqui showed differences exist in the elements concentrations and a simple inspection of the data can not be used to differentiate the chemical groups. Therefore, two multivariate methods, cluster and discriminant analysis, were applied for examining the chemical composition data. The combination of the associated cluster and discriminant analysis proved to yield useful results for the elemental concentration data sets used in this work. Until the present moment, three different compositional groups can be assigned to Monte Castelo archaeological site. These preliminary results provide evidence that the Monte Castelo ceramic were manufactured from at least three different clay sources.

The result of the thermoluminescence dating of six ceramic fragments allowed to verify that the age of the fragments varies according to the groups, with Group 1 being the oldest. However, the ages found are in agreement with the range of occupation considered for the sambaqui in the literature [23] and suggest that the ceramics associated with the bacabal ceramist culture have occupied the sambaqui at about 3000 b.P., extending up to 1500 b.P. In this way, the results of this work corroborate with miller's studies and support the hypothesis that the Bacabal's phase is one of the oldest ceramic technologies of the continent and the Monte Castelo archaeological site has the oldest contexts of production of ceramics in the Southwest Amazon. 


\section{ACKNOWLEDGMENT}

The authors wish to thank Comissão Nacional de Energia Nuclear (CNEN), for the financial support.

\section{REFERENCES}

1. LIMA, T. A. Cultura material: a dimensão concreta das relações sociais. Boletim do Museu Paraense Emílio Goeldi Ciências Humanas, v. 6, p. 11-23, 2011.

2. VELDE, B.; DRUC, I. C. Archaeological ceramic materials: origin and utilization, Berlin: Springer, 1999.

3. WEIGAND, P. C.; HARBOTTLE, G.; SAYRE, E. V. Turquoise sources and source analysis: Mesoamerica and the Southwestern U.S.A, New York: Academic Press Inc., 1977.

4. GLASCOCK, M. D.; NEFF, H.; VAUGH, K. J. Instrumental neutron activation analysis and multivariate statistics for pottery provenance. Hyper Interact, v. 154, p. 95-105, 2004.

5. MUNITA, C. S. Contribuição da análise por ativação com nêutrons a estudos arqueométricos: estudo de caso. Canindé, v. 6, p. 159-181, 2005.

6. MINCL, L. D.; SHERMAN, R. J. Assessing natural clay composition in the valley of Oaxaca as a basis for ceramic provenance studies. Archaeometry, v. 53, p. 285-328, 2011.

7. MICHELAKI, K.; HANCOCK, R. G. V. Chemistry versus data dispersion is there a better way to assess and interpret archaeometric data. Archaeometry, v. 53, p. 1259-1279, 2011.

8. SÁNCHEZ, J. S.; TRINDADE, M. J.; ROTEA, R. B.; GARCIA, R. B.; MOSQUERA, D. F.; BURBIDGE, C.; PRUDÊNCIO, M. I.; DIAS, M. I. Chemical and mineralogical characterization of historic mortars from the Santa Eulalia de Bóveda temple, NW Spain. Journal of Archaeological Science, v. 37, p. 2346-2351, 2010.

9. HANCOCK, R. G. V.; CARTER, T. How reliable are our published archaeometric analyses? Effects of analytical techniques through time on the elemental analysis of obsidians. Journal of Archaeological Science, v. 37, p. 243-250, 2010.

10. SANTOS, J. O.; MUNITA, C. S.; TOYOTA, R. G.; VERGNE, C.; SILVA, R. S.; 
OLIVEIRA, P. M. S. The archaeometry study of the chemical and mineral composition of pottery from Brazil's Northeast. Journal of Radioanalytical and Nuclear Chemistry, v. 281, p.189-192, 2009.

11. GLASCOCK, M. D.; NEFF, H. Neutron activation analysis and provenance research in archaeology. Measurement Science and Technology, v. 14, p. 1516-1526, 2003.

12. GLASCOCK, M. D.; SPEAKMAN, R. J.; NEFF, H. Archaeometry at the university of Missouri Research Reactor and the provenance of Obsidian arttefacts in Noth America. Archaeometry, v. 49, p. 343-357, 2007.

13. DIAS, M. I.; PRUDÊNCIO, M. I. Neutron activation of archaeological materials: an overview of the ITN NAA Laboratory, Portugal. Archaeometry, v. 49, p. 383-393, 2007.

14. TITE, M. S. Ceramic production, provenance and use - a review. Archaeometry, v. 50, p. 216-231, 2008.

15. MUNITA, C. S.; PAIVA, R. P.; ALVES, M. A.; OliVEIRA, P. M. S.; MOMOSE, E. F. Provenance study of archaeological ceramic. J. Trace Microprobe Tech, v. 21, p. 695-697, 2003.

16. MCKEEVER, S. W. S. Thermoluminescence of Solids, Cambridge: Cambridge University Press, 1985.

17. BARTOLL, J.; IKEYA, M. Dating of pottery: a trial, Appl. Radiat. Isot., v. 48, p. 981-984, 1997.

18. AITKEN, M. J. Thermoluminescence Dating, London: Academic Press, 1985.

19. ROOSEVELT, A. C. Arqueologia Amazônica, São Paulo: Companhia das Letras, 1992.

20. MONGELÓ, G. Z. Ocupação indígena no sítio do Brejo, Alto Rio Madeira, Rondônia: análise da cerâmica arqueológica. Available at: <http://www.arqueologia.unir.br/downloads/5 997_santos_ocupacao_indigena_no_sitio_do_brejo__analise_ceramica,_2015.pdf>. Last accessed: 01 Dec. 2017.

21. NEVES, E. G. Sob os Tempos Do Equinócio: Oito Mil Anos de História na Amazônia Central (6.500 AC - 1.500 DC), Tese de Livre Docência, Museu de Arqueologia e Etnologia da USP, São Paulo, Brasil (2013).

22. MUNITA, C. S.; PAVIA, R. P.; AlveS, M. A.; OliveIRA, P. M. S.; MOMOSE, E. F. Contribution of neutron activation analysis to archaeological studies. J. Trace and microprobe 
techniques, v. 18, p. 381-387, 2000.

23. MILLER, E. TH. Pesquisas arqueológicas no Pantanal do Guaporé: a sequência seriada da cerâmica da Fase Bacabal, Tocantins: Porto Nacional, 2009.

24. TATUMI, S. H.; RIBEIRO, R. B.; CANO, N. F.; MUNITA, C. S.; WATANABE, S.; ROCCA, R. R.; NEVES, E. G.; TAMANAHA, E. K. A preliminary study of archaeological ceramics from the São Paulo II archaeological site by INAA. Available at: <http://repositorio.ipen.br:8080/xmlui/bitstream/handle/123456789/17719/18507.pdf?sequence= 1\&isAllowed=y>. Last accessed: 01 Dec. 2017.

25. BISHOP, R. L.; CANOUTS, V.; GROWN, P. L.; ATTAS, M.; ATLEY, S. P. Sensitivity precision, and accurancy: Their roles in ceramic compositional data bases. American Antiquity, v. 55, p 537, 1990.

26. ATTAS, M.; FOSSEY, J. M.; YAFFE, L. Corrections for drill-bit contamination in sampling ancient pottery for neutron activation analysis. Archaeometry, v. 26, p. 104-107, 1984.

27. BEIER, T.; MOMMSEN, H. Modified Mahalanobis filters for grouping pottery by chemical composition. Archaeometry, v. 36, p. 287-306, 1994.

28. SAYRE, E. V. Brookhaven procedures for statistical analysis of multivariate archaeometric data, New York: Brookhaven National Laboratory Report BNL-21693, 1975.

29. KOCH, G. S.; LINK, R. F. Statistical analysis of geological data, New York: Courier Dove Publications, 2002.

30. OLIVEIRA, P. M. S., MUNITA, C. S. Influência do valor critico na detecção de valores discrepantes em arqueometria, In: SIMPÓSIO DE ESTATÍSTICA APLICADA À EXPERIMENTAÇÃO AGRONÔMICA, 2003, Lavras. Annals... Lavras: 10 SEAGRO, 2003.

31. MEGGERS, B. El contexto Ecológico del formative in Ledengerber, P. Formativo Sudamericano: uma Revaluacíon. Quito, v. 56, p. 801-823, 1992.

32. MEGGERS, B., EVANS, C., ESTRADA, E. Early Formative Period of Coastal Ecuador: The Valdivia and Machalilla Phases, Washington: Smithsonian Institute, 1965. 